Indonesian Journal of EFL and Linguistics

Vol. 4 No. 2, 2019

eISSN: 2503-4197, pISSN: 2527-5070

www. indonesian-efl-journal.org

\title{
Rhetorical Structures of English-Major Undergraduate Thesis Introduction Chapters
}

\author{
Ruth Dewi Indrian \\ English Language Education Study Program \\ Sanata Dharma University \\ e-mail: ruthdewiindrian@yahoo.com \\ Priyatno Ardi \\ English Language Education Study Program \\ Sanata Dharma University \\ Corresponding e-mail: priyatnoardi@usd.ac.id
}

\begin{abstract}
:
Undergraduate students are required to write a thesis to obtain a degree. One of the most important chapters in the thesis is introduction. Introduction section plays an important role because it describes what the research is all about. To write an introduction chapter, Swales (1990) proposed Create-a-Research-Space (CARS) model, which includes three moves, namely establishing a territory, establishing a niche, and occupying the niche. Every move consists of several steps. This study aims to analyze Swales' CARS model in the introduction chapters of undergraduate theses written by English major students. Furthermore, the lexical and syntactical signals in each move and step are investigated. This research employed discourse analysis, which focuses on how texts are structured. The researchers analyzed 18 introduction chapters of undergraduate theses written by the English major students of Sanata Dharma University who graduated in 2017. In analyzing the corpus, the researchers used top-down analysis. The results showed that Move 1, Establishing a territory, appeared in the undergraduate theses. However, many of the students did not review the previous research. Move 2, Establishing a niche, was presented in
\end{abstract}


Ruth Dewi Indrian and Priyatno Ardi

three theses. In this stage, many of the students did not fill in the gap about the previous research. Move 3, Occupying the niche, was frequently used by the students. In this phase, the students outlined the purpose of their research. This study also found that the lexical and syntactical signals used in the theses were quite different from Swales' CARS model.

Keywords: Introduction, Swales' CARS, Undergraduate Thesis

\section{INTRODUCTION}

To obtain an undergraduate degree, university students in Indonesia are often required to write an undergraduate thesis. It is the first time for them to conduct research and they have to investigate a problem and report it in the form of an undergraduate thesis. An undergraduate thesis generally consists of six chapters, one of which is introduction. Writing a research introduction itself is the hardest step for either native speakers or non-native speakers (Swales \& Feak, 2012). Even though it is often considered hard, an effective introduction demonstrates the aim and the field of the study (Bailey, 2011). According to Noorzan \& Page (2012), the introduction is important due to four reasons. First, introduction describes why the research is conducted. Second, it helps readers to understand the objectives and problems of the study. Third, it is crucial for the writer to prevent assumptions. Last, it explains the hypothesis of the study. Hereupon, it can be inferred that the introduction section plays an important role in academic writing.

Swales' CARS (Create-a-Research-Space) model is one of guidelines for students in writing introductions. Swales' CARS model proposed by Swales (1990) has been regarded as a powerful approach in descriptive and pedagogical terms. Swales (2004) states that this model has been used in international journals because it "... primarily reflects research in a big world, in big fields, in big languages, with big journals, big names, and big libraries" (p. 226). Swales' CARS model is highly recommended for writing introduction in big fields due to the reason that it is simple, functional, corpus-based, and sui-generis (p. 226).

There are now considerable evidences of the analysis Swales' CARS model in research article introductions in different sub-disciplines. Firstly, Eliana (2009) compared 20 research article introductions in Brazilian Portuguese and in English within a subfield of applied linguistics. The researcher used Swales' (1990) CARS framework. The results showed that the model in English research article introductions was more applicable than that in Brazilian Portuguese research article introductions. It shows that the organizational structure of the research articles is also influenced by the cross-cultural differences. Secondly, Irawati, Saukah, \& Suharmanto (2018) investigated 7 Indonesian authors who have published 1 English research article and 1 Indonesian research article in Indonesian journals. The focus of the research was on how Indonesian authors write their English and Indonesian 
research article discussion sections. The researchers used Swales' CARS model (1990) as the framework of analysis. The results showed that the rhetorical structures of English and Indonesian research articles followed the patterns which are different from Swales' (1990) model.

To date, there has been no sufficient research that examines the rhetorical organization of the introduction chapter of undergraduate theses. However, there is a study on the analysis of Swales' CARS model on the research proposal introductions of English Language Education Study Program students conducted by Fudhla, Rozimela, and Ningsih (2014). Yet, the researchers do not provide a clear coding of the findings. The researchers do not investigate lexical and syntactical characteristics of each move and step. Hence, it is essential to provide a deeper analysis of how Swales' CARS model is applied in the thesis introductions written by Indonesian English learners.

Therefore, the main purpose of the present study is to examine the research background in the introduction chapter of undergraduate theses written by English major students of Sanata Dharma University, Indonesia. This study seeks to investigate how Swales' CARS model is reflected in undergraduate theses and how the lexical and syntactical signals are used in each move and step.

\section{LITERATURE REVIEW}

\subsection{Introduction Section in Academic Works}

In academic writings, introduction is the first section to write. It explains the scope of the research and describes what the research is all about (Evans, Gruba, \& Zobel, 2014). Generally, it presents the structure of the thesis, the objectives and scope of the research, the problem that is investigated, and the limitation on the scope of the study. However, in some fields, introduction covers an overview of the research findings. It can help the readers to understand the context of the research by presenting illustrative examples. According to Lipson (2005), introduction is the most decisive chapter because through this section the writers are required to write enticing paragraphs so that they can convince and engage the readers to read further. For that reason, the writers need to present the major arguments of the issue by presenting clear and effective thesis statements and the main questions that they want to investigate. There are three things that the writers have to provide in the introduction chapter. Firstly, the topic chosen has to offer beneficial insights to the reason why the issue is important to be discussed. They have to clarify it both in practical terms and theories. Secondly, the writers have to present the methods used to examine the problem. Thirdly, the writers need to provide the proofs that they will rely on to support the research. 
Ruth Dewi Indrian and Priyatno Ardi

\subsection{Moves in Introduction Section}

Swales (2004) defines move as a "... discoursal or rhetorical unit that performs a coherent communicative function in a written or spoken discourse" (p. 228). It includes a grammatical unit, such as a sentence, utterance, paragraph, and clause. On one hand, grammatical features can also indicate the genre of a move (p. 228-229). There are some proposed theories of genre analysis in the introduction chapter. The theories present the rhetorical structures (moves and steps) used to be the guideline in writing introduction section. There are two models, namely Swales' CARS model and Lewin, Fine, \& Young's model.

\subsubsection{Swales' CARS Model}

Swales' CARS (Create-a-Research-Space) model is a seminal work proposed by Swales (1990). This model presents the phases used to be the protocol for writing research article introductions. It has been used in international journals because it "... primarily reflects research in a big world, in big fields, in big languages, with big journals, big names, and big libraries" (Swales, 2004). Swales' CARS model has three move structures which consist of several stages. Each move and step present the communicative function. In this model, Swales also proposes lexical and syntactical signals used to indicate the moves and steps. The lexical signals focus on specific words to signalize the move and step structures. Therefore, the syntactical signals indicate the sentence patterns of move and step structures. The framework and lexical and syntactical signal of each move and step are described below.

1. Move 1: Establishing a territory

In this stage, the researchers need to claim a certain point that will be discussed in the research and review arguments of previous research (Swales \& Feak, 2012).

a. Step 1: Claiming centrality

Writing Action: Describing why the topic area study is important, central, problematic, or relevant in some way.

1) ... there has been growing interest in ...

2) ... has become an important aspect of ...

3) ... has become a major issue ...

4) ... remains a serious problem ...

b. Step 2: Making topic generalization

Writing Action: Providing statements about the current state of knowledge, practice or description of phenomena.

1) The aetiology and pathology ... is well known.

2) A standard procedure for assessing has been ... 
c. Step 3: Reviewing items of previous research

Writing Action: Reviewing previous studies which are relevant to the present study.

1) There are many situations where ...

2) Several researchers have studied the causes of ...

3) There have been several investigations into ...

4) Huang (2007) investigated the causes of ...

2. Move 2: Establishing a niche

Swales \& Feak (2012) state that this phase describes a specific area that requires a further investigation of the previous research.

a) Step 1A: Counter-claiming

Writing Action: identifying a gap in previous study that has weakened the prevailing argument (something is wrong).

1) These studies have emphasized ..., as opposed to ...

2) Although considerable research has been devoted to ..., rather less attention has been paid to ...

b) Step 1B: Indicating a gap

Writing Action: developing the research problem around a gap (something is missing).

1) It would be thus be of interest to learn how ...

2) It would seem, therefore, that further investigations are needed in order to ...

c) Step 1C: Question-raising

Writing Action: developing key questions about the consequences of gaps in prior research that will be addressed to the present research (something is unclear).

1) However, it remains unclear whether ....

d) Step 1D: Continuing a tradition

Writing Action: establishing the new research problem or adding the other natures of the previous research (adding something).

1) Research has tended to focus on ..., rather than on ...

2) No studies/data/calculations to date have ...

3) However, few studies ...

3. Move 3: Occupying the niche 
Ruth Dewi Indrian and Priyatno Ardi

In this move, the researcher introduces the present study in the context of the previous study drawn in Moves 1 and 2 (Swales \& Feak, 2012).

a) Step 1A: Outlining purposes

Writing Action: describing the objectives of the present study.

1) The aim of the present paper is to give ...

2) It is the purpose of the present paper to provide ...

b) Step 1B: Announcing present research

Writing Action: presenting the nature of the present study by stating the purpose of the research in terms of what the study is going to accomplish.

1) This study was designed to evaluate ....

2) The aim of the present paper is to give ....

3) The main purpose of the experiment reported here was to ....

c) Step 2: Announcing principal findings

Writing Action: presenting a brief, general summary of key findings.

1) The findings indicate a need for ...

2) The research suggests four approaches to ...

d) Step 3: Indicating research article structure

Writing Action: explaining how the paper is organized.

1) The plan of this paper is as follows.

\subsection{Previous Studies on Swales' CARS Model}

Previous studies on Swales' CARS model to RAIs in different sub-disciplines have been conducted by some researchers. First, Abdullah (2016) examined research article introductions from Language Teaching (ELT) and Civil Engineering (CE) corpora. The researcher used twelve research articles from four journals of both disciplines, namely Language Learning (LL), Foreign Language Annals (FLA), Transportation (T) and Structural Survey (SS) by using a modified CARS model of Anthony's. The results showed that in Civil Engineering (CE) corpora and Language Teaching (ELT) followed different rhetorical patterns. Second, Madrunio (2012) also investigated the move sequences of Swales' CARS model of 21 graduate research paper introductions and conclusions. Ten of those are written by MA students, while the other 11 papers were written by Ph.D. students. In this study, the researcher employed a framework proposed by Swales and Feak (1994). The results showed that the students applied Move 1 along with 2 to 3 steps. For the second move, there were 10 papers established the Move 2 Step 1B Indicating a gap; the other three established the Move 2 Step 1A Counter-claiming; and the rest did not 
establish any step of the move. With regard to Move 3, the majority of the occurrences were Move 3 Step 1A Outlining purposes and Step 1B Announcing present research. Third, Irawati, Saukah, \& Suharmanto (2018) investigated how Indonesian authors write their English and Indonesian research article (RA) discussion sections. In this study, the researchers employed Swales' CARS model (1990). They examined 7 Indonesian authors who have published 1 English RA and 1 Indonesian RA in Indonesian journals. The result showed that the rhetorical structures in terms of move occurrences and move order of English and Indonesian research article discussion sections were different from Swales' (1990) model. Last, Fudhla, Rozimela, and Ningsih (2014) conducted a study on the analysis of Swales' CARS model on the research proposal introductions of English Language Education Study Program students. In this study, the researcher used Swales and Feak's framework (2012). The results showed that the niche of the first move was still too general and there were a lot of repetitions of the problem discussed. For the second move, the researchers did not find any move and step applied in the papers. Therefore, the research problem of the present study was not described clearly. For the third move, the aims and questions of the research were not delivered well and fit to the research problem.

\section{RESEARCH METHODOLOGY}

This research employed discourse analysis. The researchers analyzed undergraduate theses, focusing on the introduction structures. The text structures of undergraduate theses were analyzed by using rhetorical structures (moves and steps) of Swales' CARS model (1990). To analyze the rhetorical structure of the thesis introduction chapters, the researchers dealt with discourse markers which link to how the texts are structured.

The object of this study was the introduction chapters of undergraduate theses written by English major students of Sanata Dharma University in Indonesia who graduated in 2017. The researchers used random sampling to determine the samples of the theses. The samples were taken from three sub-disciplines of the theses, namely (1) English language teaching, which focuses on an exploration of the instruction and acquisition of the language skills; (2) English linguistics, which focuses on an exploration of issues in linguistic areas; and (3) English literature, which focuses on literary works (PBI Thesis Guideline, 2018). Each of subdisciplines was equally represented by six introduction chapters. The introduction chapters of the three sub-disciplines have the same sub-headings. Therefore, the researchers analyzed the rhetorical moves in the introduction chapters focusing only on the background of the study by using Swales' CARS model (1990). Table 3 shows the coding category for sub-disciplines. 
Ruth Dewi Indrian and Priyatno Ardi

Table 1: Sub-discipline code

\begin{tabular}{|c|l|c|}
\hline No. & \multicolumn{1}{|c|}{ Sub-disciplines } & Code \\
\hline 1. & English Language Teaching & ELT \\
\hline 2. & English Linguistics & EL \\
\hline 3. & English Literature & ELit \\
\hline
\end{tabular}

As Biber, Conor, \& Upton (2007) suggest, to conduct a discourse analysis on the move, the researchers implemented top-down corpus-based analyses. There were seven phases of this approach, namely (1) communicative/functional categories, (2) segmentation, (3) classification, (4) linguistic analysis of each unit, (5) linguistic description of discourse categories, (6) text structure, and (7) discourse organizational tendencies (p. 13). Lastly, the researchers presented the model of general structural patterns of undegraduate thesis structures across all texts in the corpus. To validate the data, the researchers repeatedly checked the classification of each move and step occurrence. During the checking process, the researchers found some mistakes and then recoded the mistakes.

Table 2 shows the coding of moves and steps. The codes were designed based on the initial letter of move and step.

Table 2: Move and step code

\begin{tabular}{|l|l|}
\hline Move and Step & Code \\
\hline Move 1 & M1 \\
\hline Move 1 Step 1A & M1S1A \\
\hline Move 1 Step 1B & M1S1B \\
\hline Move 1 Step 2 & M1S2 \\
\hline \multicolumn{2}{|l|}{} \\
\hline Move 2 & M2 \\
\hline Move 2 Step 1A & M2S1A \\
\hline Move 2 Step 1B & M2SIB \\
\hline Move 2 Step 1C & M2SIC \\
\hline Move 2 Step 1D & M2SID \\
\hline \multicolumn{2}{|l}{} \\
\hline Move 3 & M3 \\
\hline Move 3 Step 1A & M3S1A \\
\hline Move 3 Step 1B & M3S1B \\
\hline Move 3 Step 2 & M3S2 \\
\hline Move 3 Step 3 & M3S3 \\
\hline
\end{tabular}




\section{FINDINGS AND DISCUSSION}

\subsection{Swales' CARS model identified in introductions of undergraduate theses}

In this study, some moves and steps of Swales' CARS model were found in all three sub-disciplines (ELT, Ling, and Lit). The number of occurrences of each and step are presented in Table 3.

Table 3: Move and step occurrences in thesis introductions

\begin{tabular}{|c|c|c|c|c|c|c|c|}
\hline \multirow{2}{*}{ Code } & \multicolumn{2}{c|}{ ELT (n=6) } & \multicolumn{2}{c|}{ Ling (n=6) } & \multicolumn{2}{c|}{ Lit (n=6) } \\
\cline { 3 - 8 } & N & \% & N & \% & N & \% \\
\hline \multirow{3}{*}{ Move 1 } & M1S1 & 4 & $68 \%$ & 1 & $17 \%$ & 1 & $17 \%$ \\
\cline { 2 - 8 } & M1S2 & 6 & $100 \%$ & 6 & $100 \%$ & 4 & $68 \%$ \\
\cline { 2 - 8 } & M1S3 & 1 & $17 \%$ & 2 & $34 \%$ & 0 & $0 \%$ \\
\hline \multirow{3}{*}{ Move 2 } & M2S1A & 0 & $0 \%$ & 0 & $0 \%$ & 0 & $0 \%$ \\
\cline { 2 - 8 } & M2SIB & 0 & $0 \%$ & 0 & $0 \%$ & 0 & $0 \%$ \\
\cline { 2 - 8 } & M2S1C & 0 & $0 \%$ & 0 & $0 \%$ & 0 & $0 \%$ \\
\cline { 2 - 8 } & M2S1D & 1 & $17 \%$ & 2 & $34 \%$ & 0 & $0 \%$ \\
\cline { 2 - 8 } & M3S1A & 0 & $0 \%$ & 0 & $0 \%$ & 0 & $0 \%$ \\
\cline { 2 - 8 } & M3S1B & 6 & $100 \%$ & 5 & $85 \%$ & 4 & $68 \%$ \\
\cline { 2 - 8 } & M3S2 & 0 & $0 \%$ & 0 & $0 \%$ & 0 & $0 \%$ \\
\cline { 2 - 8 } & M3S3 & 0 & $0 \%$ & 0 & $0 \%$ & 0 & $0 \%$ \\
\hline
\end{tabular}

The results showed that all of the sub-disciplines occupied Move 1, Establishing a Territory. However, not all of the writers presented Move 1 Step 1, namely Claiming Centrality. The highest occurrence appeared 68\% in ELT, while the lowest occurrence appeared 17\% in English Linguistics and English Literature. Therefore, 100\% ELT and English Linguistics occupied Move 1 Step 2, namely Making Topic Generalization. Some of the writers still explained this move generally. They did not focus on the topic of their study. It is in line with Fudhla, Rozimela, \& Ningsih (2014), who stated that this move was still too general. Move 1 Step 3, Reviewing Items of Previous Research, was infrequently used. The occurrence was 17\% in ELT and $34 \%$ in English Linguistics. The move and step were not found in English Literature theses. The examples of the occurrences in move 1 across all three subdisciplines are as follows.

(1)Learning English as a second language is somehow problematic .... Therefore, the researcher thinks that it is necessary to study politeness strategies in ... (ELT1_P3/S3) (M1S1)

(2)Petri (1981) describes motivation is the concepts we use when .... (ELit6_P2/S2) (M1S2)

(3)Some research had proven that some characteristics show ... (EL1_P2/S4) (M1S3) 
It can be seen from the examples given above that, in M1S1 (ELT1_P3/S3), the writer presented the research problem and evidence to support why the study needs conducting (Swales, 1990). The writer used the word therefore as the transition signal to relate the problem of the study to the importance of conducting the research. Here, the sentence used to show its importance was it is necessary to study .... Hence, this sample occupied Move 1 Step 1.

In M1S2 (ELit6_P2/S2), the sentence generalized the topic by providing supporting knowledge and phenomena. The sentence used to indicate that the writer presented the supporting knowledge was Petri (1981) describes motivation is the concepts we use when .... The word describes here was used to define Petri's theory which was believed as the knowledge and current phenomena to support the study.

The occurrence in M1S3 (EL1_P2/S4) showed that the writer reviewed previous research that supports the study. The writer used the sentence Some research had proven that ... to indicate that some previous studies have been believed to support the need of the present study. Madrunio (2012) also stated that this move only occurred 3 out of 11 introductions. Many of the writers still did not review the previous research. However, this move is required to lead to Move 2, namely Establishing a Niche.

Move 2, Establishing a Niche (M2S1D Continuing a Tradition), occurred 17\% in ELT and 34\% in English Linguistics (M1S1D). However, the researchers did not find the move and step in English Literature. In addition, the occurrence of Move 1 Step 1A Counter-claiming, Move 2 Step 1B Indicating a Gap, and Move 2 Step 1C Question-raising were not found in the samples. The researchers found that this move was infrequently used. Many of the samples did not review previous research and develop the research problem around the gap. This supports Fudhla, Rozimela, \& Ningsih (2014) who found that this move did not appear in the research proposal introductions. It shows that many writers did not review the previous studies. Therefore, it is clear that this move is infrequently used. The examples of the occurrences in move 2 across all three sub-disciplines are as follows.

(4)Hence, the researcher has checked the previous research ... The contain of the study defines about the linguistic features of women's language only .... For this reason, the researcher tries to compare ... (EL1_P5/S1) (M2S1D)

The example shows that the writer reviewed the previous research and tried to establish the gap of the present study. M2S1D, namely Continuing a Tradition, describes the problem of the present study by previewing the previous research that is still insufficient. Here, the writer needs to fill in the gap by establishing the new problem or adding the other natures of the previous research. In M2S1D (EL1_P5/S1), the writer used the words ... the researcher has checked the previous research ... to indicate that he had studied the previous research that still needed improvement because he stated The contain of the study defines about the linguistic 
features of women's language only. The word only here shows that the study still needed improvement. Therefore, he stated the sentence the researcher tries to compare to indicate a new gap that he wanted to discover.

Move 3, namely Occupying the Niche, appeared in all the three sub-disciplines. The occurrence appeared in Move 3 Step 1B, Announcing Present Research, with 100\% in ELT, 85\% English Linguistics, and 68\% in English Literature. However, Move 3 Step 2, Announcing Principal Findings, and Move 2 Step 3, Indicating Research Article, were not found in all sub-disciplines. Madrunio (2012) also stated that this move was frequently used rather than other moves. In his study, the steps mostly occurred in M3S1A, Outlining Purposes, and M3S1B, Announcing Principal Findings. In this study, the researchers also discovered that all writers occupied M3S1A, Outlining Purposes. Here are the examples of the occurrences in move across all three sub-disciplines.

(5)Therefore, the researcher conducted this study to help ... (ELT2_P8/S1) (M3S1B)

(6)Considering the phenomenon of ..., the writer proposed to study further about ... (EL5_P4/S1) (M3S1B)

(7)This study report an analysis of Aibileen Clark's motivation ... (ELit6_P7/S1) (M3S1B)

The examples show that the writers presented the purpose of the study and described what they were going to accomplish in their research. The writers used the lexical signals therefore and considering the phenomena to indicate the present research that would be investigated. The researchers used the syntactical signals such as ... the researcher conducted this study, ..., the writer proposed to study ..., This study report an analysis of ... to show the nature of the research. The move and step sequences across all sub-disciplines are presented in Table 4.

Table 4: Move and step sequences of thesis introductions

\begin{tabular}{|c|l|}
\hline Text & \multicolumn{1}{|c|}{ Move-step sequences } \\
\hline ELT 1 & M1S1 - M1S2 - M1S3 - M1S2 - M3S1B \\
\hline ELT 2 & M1S2 - M1S1 - M3S1B \\
\hline ELT 3 & M1S2 - M3S1B \\
\hline ELT 4 & M1S2 - M3S1B \\
\hline ELT 5 & M1S1 - M1S2 - M3S1B \\
\hline ELT 6 & M1S1 - M1S2 - M1S1 - M2S1D - M3S1B \\
\hline \multicolumn{2}{|l}{} \\
\hline EL 1 & M1S2 - M1S3 - M2S1D - M1S2 - M2S1D - M3S1B \\
\hline EL 2 & M1S2 - M1S1 - M1S2 - M3S1B \\
\hline EL 3 & M1S2 - M2S1D \\
\hline EL 4 & M1S2 - M3S1B \\
\hline EL 5 & M1S2 - M3S1B \\
\hline EL 6 & M1S2 - M1S3 - M1S2 - M3S1B \\
\hline
\end{tabular}


Ruth Dewi Indrian and Priyatno Ardi

\begin{tabular}{|l|l|}
\hline \multicolumn{2}{|l|}{} \\
\hline ELit 1 & M1S2 - M1S1 - M1S2 \\
\hline ELit 2 & M3S1B \\
\hline ELit 3 & M3S1B - M1S2 - M3S1B \\
\hline ELit 4 & M1S2 \\
\hline ELit 5 & M3S1B \\
\hline ELit 6 & M1S2 - M3S1B \\
\hline
\end{tabular}

Based on the findings, not all of the theses occupied the move and step in accordance with Swales' CARS model. The starting point of the introduction section of English language teaching theses was started by making topic generalization (M1S2) and claiming centrality (M1S1). The second step was followed by Move 1 Step 3, Reviewing items of previous research. The third stage was occupied by Move 2 Step 1D, Continuing a Tradition, but the occurrence only appeared in one sample only. Lastly, Move 3 Step 1B, Announcing Present Research, occurred in all introduction chapters. The sequence was similar to Swales' CARS model. In addition, the researchers also found that the occurrence of Move 1 Step 3, Reviewing Items of Previous Research, and Move 2, were infrequently found in all ELT theses, whereas these moves and steps were obligatory.

In English Linguistics theses, the move and step began with Step 1 Move 2, Making Topic Generalization, and only one sample that occupied Move 1 Step 1, Claiming Importance. Therefore, some introduction chapters presented Move 1 Step 1, Claiming Importance, and Move 1 Step 3, Reviewing Items of Previous Research. The next stage, there were only two introductions that occupied Move 2 (M2S1D Continuing a Tradition). Lastly, Move 3 Step 1B, Announcing Present Research, appeared in 5 introduction chapters.

In English Literature theses, the first stage was occupied by Move 1 Step 2, Making Topic Generalization, and Move 3 Step 1B, Announcing Present Research. There was only one sample that presented Move 1 Step 1 Claiming Importance after M1S2. Therefore, the last stage was followed by Move 3 Step 1B, Announcing Present Research, and the occurrence only appeared in 4 out of 6 theses. There were three introductions that presented M1S2 only and one introduction only presented M1S2. Many of the writers did not write Move 2, Establishing the Niche, in the background of the study, whereas this move is obligatory and essential. Most of them wrote the summary of the object of the study rather than generalizing the topic area.

In conclusion, in all 18 samples, the writers began the introduction section by writing Move 1 Step 2. The occurrence of M1S1, M1S3, and M2S1A only appeared in a few of samples, while the others did not present these steps. Move 3 (M3S1B Announcing Present Research) occurred in 16 out of 18 samples. Since Move 3 Step 2, Announcing Principal Findings, and Step 3 Step 3 Indicating Research Article Structure, are optional and only present in some fields, the researchers did not find 
them in the theses. In this study, the researcher found that the writers employed Move 1, 2, and 3. However, Madrunio (2012) revealed that the common sequence of graduate research paper was not in accordance with Swales' CARS (Move 1, 3, and 2 ). The writers concluded the introduction section by providing Move 2 Indicating a Gap and Counter-claiming. Therefore, the move sequence is different from one another depending on the culture and rule of writing introduction.

\subsection{Lexical and syntactical signals used in each move and step}

In this section, the researchers present the typical lexical and syntactical signals found in the research background. As described in the literature review of Swales' CARS model, these signals are used to identify each move and step.

\subsubsection{Move 1: Establishing a Territory}

In this stage, the writer needs to claim a certain point that will be discussed in the research and review arguments of previous research.

Step 1: Claiming Centrality

To claim centrality, the writer needs to show that the topic area is important, central, problematic, or relevant in some way (Swales \& Feak, 2012). The lexical and syntactical signals used to indicate the appearance of Move 1 Step 1 are:

... there has been growing interest in ...

... has become an important aspect of ...

... has become a major issue ...

... remains a serious problem ...

However, the transition signals used in the undergraduate thesis introduction structures were different from Swales' CARS model. The findings are as follows:

(8)In English subject, reading plays an important role because most of the information nowadays are presented in the form of text. (ELT5_P2/S1)

(9)Nevertheless, managing the students is one of the most important things in a classroom. (ELT5_P4/S4)

(10) Therefore, the researcher thinks that it is necessary to study politeness strategies in spoken refusals, especially for the English learners who deal with English language in their works later on. (EL2_P3/S5)

First, in ELT5_P2/S1, the writer used the lexical signals “... reading plays an important role ..." to indicate that the topic is problematic and essential to study because he found that "... most of the information nowadays are presented in the form of text." Second, in ELT5_P4/S4, it is stated that "Nevertheless, managing the students is one of the most important things." The writer used the word "nevertheless" to indicate that something was not in accordance with the reality of 
"managing the students is one of the most important things". Therefore, this shows that the study is problematic. Third, EL2_P3/S5 states "Therefore, the researcher thinks that it is necessary to study politeness strategies in spoken refusals ...." The writer used the lexical signal "therefore" to show that there was a problem caming up so that he thought that the study about politeness strategies needed conducting. As discussed, the lexical and syntactical signals used by the undergraduate introduction sections are quite different from Swales' CARS model. However, the signals are still acceptable because it can be used to indicate the occurrence of Move 1 Step 1.

\section{Step 2: Making Topic Generalization}

Swales \& Feak (2012) state that in making topic generalization, the writer needs to present statements about the current state of knowledge, description of phenomena of the research area, and the definition of terms. There are some lexical and syntactical signals used in this stage, such as:

The aetiology and pathology ... is well known.

A standard procedure for assessing has been ...

There are many situations where ...

The researchers found that the lexical and transition signals used were quite different. However, the signals clearly indicate the occurrence of this stage. The findings are as follows.

(11) Pronunciation, according to Nunan (2003), is the sounds that we produce when we speak. (ELT2_P5/S1)

(12)According to Unger (1979), gender is defined as social label, the traits and behavior that are regarded by the culture to men and women (as cited in Brannon, 1996,p.11). (ELit1_P1/S1)

(13)According to Richard, Platt, and Platt (1992), politeness is an attempt to establish, maintain, and save someone's face during a conversation. (EL2_P2/S2)

Firstly, in ELT2_P5/S1, the writer stated "Pronunciation, according to Nunan (2003), is the sounds that ..." as the lexical and syntactical signals to generalize the meaning of pronunciation. This sentence gives the definition of terms used to support the study which focused on pronunciation. Secondly, in ELit1_P1/S1, it is stated "According to Unger (1979), gender is defined as ..." The writer used the transition signals "According to ..." to indicate that she used Unger's theory to present the definition of gender. This sentence shows that the writer provided the definition of terms used to advocate the research area. Thirdly, in EL2_P2/S2, the writer stated "According to Richard, Platt, and Platt (1992), politeness is ..." In this stage, the writer generalized the current state of knowledge of politeness by 
presenting Richard, Platt, and Platt's theory. In short, the writers tend to use theories to present the current state of knowledge, phenomena, and definition of terms as the topic generalization of the present study. The lexical and syntactical signals used in the introduction sections tend to use "according to ..." and were followed by the definition of the terms of the current state of knowledge.

Step 3: Reviewing Items of Previous Research

In this stage, the writer reviews previous studies which are relevant to the study. This stage also presents important findings that advocate the needs to investigate the research problem (Swales \& Feak, 2012). There are some lexical and syntactical signals used in this stage, such as:

Several researchers have studied the causes of ...

There have been several investigations into ...

Huang (2007) investigated the causes of ...

The researchers found that the lexical and syntactical signals used by the undergraduate students were similar to Swales' CARS model. The examples are as follows.

(14) Moreover, Wood (2001), investigated the use of a learning tool and concluded that "game-like formats could be more effective at capturing learners" attention than traditional media such as textbooks" (cited by Yip \& Kwan, 2006, p. 234). (ELT1_P9/S1)

(15) Some research had proven that some characteristics show the differences between women's language and men's language. (EL1_P2/S4)

(16) Sert (2004) has investigated that the functions of code switching for students are known as equivalence, floor-holding, reiteration, and conflict control. (ELing6_P1/S7)

First, in ELT1_P9/S1, the writer used the transition signal "moreover" to indicate that there was a study that supported the present study. He also used the words "investigated and concluded" to review previous research on game-like formats. The lexical and syntactical signals used were similar to Swales' model, aiming to give supporting ideas for the current research problem. Second, in EL1_P2/S4, it is stated that "Some research had proven that ...." The writer used this sentence to show that there were relevant studies to the present study. The signals were similar to Swales' example, "There have been several investigations into ...," to indicate the occurrence of this stage. Third, in EL6_P1/S7, the writer used the signals "Sert (2004) has investigated that ..." to review Sert's study which had the relevancy for the present study. The structure of the sentence, started from the subject, the year of the research, then followed by the word "investigated" is similar to Swales' model "Huang (2007) investigated the causes of ..." In conclusion, the lexical and 
Ruth Dewi Indrian and Priyatno Ardi

syntactical signals used by the undergraduate introduction sections were similar to Swales' CARS model. The transition signals used in the introduction sections tend to use the word "investigate" to review the previous research.

\subsubsection{Move 2: Establishing a Niche}

In this stage, the writer needs to indicate a gap of the previous research and extend the previous knowledge (Swales, 1990).

Step 1D: Continuing a Tradition

This stage describes the problem of the present study by previewing the previous research that is still insufficient. Here, the writer needs to fill in the gap by establishing the new problem or adding the other natures of the previous research (Swales \& Feak, 2012). There are some lexical and syntactical signals used in this stage, such as:

Research has tended to focus on ..., rather than on ...

No studies/data/calculations to date have ...

However, few studies ...

This study found that the lexical and syntactical signals used were quite different. However, the signals clearly indicate the occurrence of this stage. The findings are as follows:

(17) The classroom management itself has been discussed by several researchers (Suprehatiningsih, 2015; Parasdya, 2015; Farita, 2005). However, the focus of their study was to find out the most effective classroom management. In this research, the researcher added an additional variable ..... (ELT5_P5/S1)

(18) Hence, the researcher has checked the previous research.... As a result, most of the studies are talking about women's language only, without comparing it with men's language.... For this reason, the researcher tries to compare the linguistic features ... and tries to analyze the difference of gossip talked by women and men. (EL1_P5/S1)

(19) The writer had already searched at Google Scholar search engine and found that there was no journal related to rhetorical figures on Facebook status updates. The writer found some journals which discuss Facebook status, such as Dimensions of Self-Expression in Facebook Status Updates written by Kramer, A. D., \& Chung, C. K. or Facebook status updates: A speech act analysis written by Joiner, $R$., et al. Therefore, the researcher would to find out what schemes and tropes of rhetorical figures are used in advertisements found in Facebook status updates specifically Adidas Originals Facebook. (EL3_P4/S1) 
Firstly, in ELT5_P5/S1, the writer used the signals "has been discussed" to show that there was a previous study talking about classroom management. He stated "However, the focus of their study was to find out ..." to indicate that the study had a particular focus. It is quite similar to Swales' signals "Research has tended to focus on ..., rather than on ..." which indicate the focus of the research. Thus, the sentence "In this research, the researcher added ..." was used to describe the present study.

Secondly, in EL1_P5/S1, the writer had already checked previous research that was relevant to his research. The signals "As a result, most of the studies are talking about women's language only, ..." indicate that there were many studies discussing women's language only. Hence, in the present study, the writer filled in the gap by comparing linguistic features and analyzing the difference of gossip talked by women and men. In this stage, the lexical and syntactical signals used were similar to Swales' lexical and syntactical signals "Research has tended to focus on ..., rather than on ..." which indicate that many studies have focused on a specific topic. Therefore, the writer tried to investigate other research problems.

Thirdly, in EL3_P4/S1, it is written that "The writer had already searched at ... and found that there was no journal ...." These signals indicate that the writer had already searched previous studies but there was no study discussing the rhetorical figures on Facebook status updates. By stating "Therefore, the researcher would to find out ..." shows that he wanted to investigate a research problem that had not been studied before. Swales' lexical and syntactical signals "No studies/data/calculations to date have ..." is reflected in this stage. The signals used was quite different; however, this sentence occupies move 2 which emphasizes on something needs to be added. In short, the lexical and syntactical signals used in the introduction sections were quite different from Swales' CARS model.

\subsubsection{Move 2: Occupying the Niche}

In this move, the writer introduces the present study in the context of the previous study drawn in Moves 1 and 2.

\section{Step 1B: Announcing Present Research}

In this phase, the writer presents the nature of the present study by stating the purpose of the research in terms of what the study is going to accomplish (Swales \& Feak, 2012). There are some lexical and syntactical signals used in this stage, such as:

This study was designed to evaluate ....

The aim of the present paper is to give ....

The main purpose of the experiment reported here was to ....

This paper reports on the results obtained .... 
Ruth Dewi Indrian and Priyatno Ardi

The researchers found that the lexical and syntactical signals used by undergraduate students were similar to Swales' CARS model. The findings are as follows.

(20) In this study, the researcher was interested to conduct a study on code switching done by an English teacher in teaching English. (EL6_P4/S1)

(21) This study reports an analysis of Aibileen Clark's motivation, ....(ELit6_P7/S1)

(22) In this research, the researcher attempts to find out English teachers' opinions in SMP Maria Immaculata about parents' interference in the school, ....(ELT5_P6/S1)

Firstly, in EL6_P4/S1, the writer used the signals "In this study, the researcher was interested to conduct a study on ..." to indicate the present research on codeswitching. Secondly, in Elit6_P7/S1, it is stated "This study reports an analysis of ....". The signals were similar to Swales' model "This paper reports on the results obtained ...." Therefore, the sentence shows that the writer described what the present research was about. Thirdly, in ELT5_P6/S1, the writer stated "In this research, the researcher attempts to find out ...." These signals indicate that the present study will be conducted by the writer. In conclusion, the lexical and syntactical signals used in the undergraduate introduction sections were similar to Swales' CARS model.

\section{CONCLUSION}

The results of this study showed that Move 1, Establishing a territory, appeared in three sub-disciplines. However, many of the writers did not review previous research. There were only 3 samples that presented Move 2, Establishing a niche. In this stage, many of the writers did not fill in the gap about the previous research, whereas this stage is obligatory. Lastly, in Move 3 Occupying the niche, the researchers found that this move was frequently used. There were only 3 introductions that did not occupy this move. In this phase, the writers presented the purpose of their present research. For the move and step sequence, generally, all the undergraduate theses did not present the move and step in accordance with Swales' CARS model. However, the lexical and syntactical signals in Move 1 and Move 3 were similar to Swales' CARS model. In Move 2, the signals were quite different from the framework.

Based on the findings, the reseachers suggest that Swales' CARS model be used as the guideline to write an introduction section of undergraduate thesis. This model presents three moves along with the steps which can help the students to write a well-organized introduction with specific patterns. Since this study only examined the moves of the introduction chapters written by English major students, further research is invited to scrutinize the rhetorical organization of the discussion chapters of undergraduate theses. As the discussion chapters are the heart of the thesis, the 
results of the research will shed light on presenting and discussing the findings in undergraduate theses.

\section{REFERENCES}

Abdullah, S. (2016). An analysis of cross-discipline research article introduction structures through a modified create a-research-space (CARS) model. EFL Journal, 1(1), 1-16.

Bailey, S. (2011). Academic writing: A handbook for international students (3rd ed.). New York: Routledge.

Biber, D., Connor, U., \& Upton, T. A. (2007). Discourse on the move: Using corpus analysis to describe discourse structure. Amsterdam: John Benjamins B.V..

Evans, D., Gruba, P., \& Zobel, J. (2014). How to write a better thesis (3rd ed.). New York: Springer International Publishing Switzerland. doi: 10.1007/978-3-31904286-2

Fudhla, N., Rozimela, Y., \& Ningsih, K. (2014). An analysis of students' research proposal introduction based on CARS model at STAIN Sjech M. Djamil Djambek Bukittinggi. Journal English Language Teaching (ELT), 2, 66-77.

Irawati, L., Saukah, A., \& Suharmanto. (2018). Indonesian authors writing their discussion sections both in English and Indonesian research articles. Cakrawala Pendidikan, 37(3), 447-456.

Lewin, B. A., \& Young, L. (2001). Expository discourse: A genre-based approach to social science research texts. London: Continuum.

Lipson, C. (2005). How to write a BA thesis: A practical guide from your first ideas to your finished paper. Chicago: The University of Chicago Press.

Madrunio, M. R. (2012). Move sequences in graduate research paper introductions and conclusions. i-manager's Journal on English Language Teaching, 2(1), 114.

Noorzan, M. N. \& Page, G. M. (2012). Writing your thesis. Kuala Lumpur: Pearson Malaysia.

Schiffrin, D., Tannen, D., \& Hamilton, H. (Eds.). (2001). The handbook of discourse analysis. Oxford: Blackwell Publishers.

Stephen, B. (2011). Academic writing: A handbook for international students. New York: Routlage.

Swales, J. M. (1990). Genre analysis. Cambridge: Cambridge University Press.

Swales, J. M. (2004). Research genres: Explorations and applications. Cambridge: Cambridge University Press.

Swales, J. M., \& Feak, C. B. (1994). Academic writing for graduate students. Ann Arbor, MI: The University of Michigan Press.

Swales, J. M., \& Feak, C. B. (2012). Academic writing for graduate students: Essential tasks and skills (3rd ed.). Ann Arbor, MI: The University of Michigan Press. 
Ruth Dewi Indrian and Priyatno Ardi

Upton, T. A. (2009). An approach to corpus-based discourse analysis: The move analysis as example. Discourse Studies, 11 (5), 585-605. doi:10.1177/1461445609341006 